\title{
Ectomycorrhizal Community on Norway Spruce Seedlings Following Bark Beetle Infestation
}

\author{
Petra Veselá ${ }^{1,2, *(1)}$, Martina Vašutová ${ }^{1,3}$, Karolína Hofmannová ${ }^{4}$, Magda Edwards-Jonášová ${ }^{1}$ \\ and Pavel Cudlín ${ }^{1}$ \\ 1 Department of Carbon Storage in the Landscape, Global Change Research Institute, Czech Academy of \\ Sciences, Lipová 1789/9, 37005 České Budějovice, Czech Republic \\ 2 Department of Carbon Storage in the Landscape, Global Change Research Institute, Czech Academy of \\ Sciences, Zemědělská 1665/1, 61300 Brno, Czech Republic \\ 3 Department of Botany, Faculty of Science, University of South Bohemia, Branišovská 31, \\ 37005 České Budejovice, Czech Republic \\ 4 Department of Forest Protection and Wildlife Management, Mendel University in Brno, Zemědělská 3, \\ 61300 Brno, Czech Republic \\ * Correspondence: vesela.p@czechglobe.cz; Tel.: +420-724-037-970
}

Received: 20 July 2019; Accepted: 23 August 2019; Published: 28 August 2019

\begin{abstract}
Ectomycorrhizal (ECM) fungi importantly influence seedling growth, nutrition, and survival and create an extensive mycelial network interconnecting tree species and enabling resource redistribution. Due to their symbiotic relationship with trees, they are impacted by forest disturbances, which are of increasing relevance due to climate change. The effect of disturbance on seedling colonization and their morphology is still largely unknown. Seedling growth parameters and the ECM fungal assemblage on the roots of Norway spruce (Picea abies (L.) H. Karst.) seedlings were assessed in mature spruce forests attacked and destroyed by bark beetle and in a mature non-attacked forest as a reference. We did not detect significant differences in number of ECM species on seedling roots among forest types, but ECM species composition changed; Tylospora fibrillosa (Burt) Donk, Meliniomyces variabilis Hambl. \& Sigler, and Phialocephala fortinii C.J.K. Wang \& H.E. Wilcox were characteristic species in the forest destroyed by bark beetle, whereas Lactarius, Cortinarius, and Russula were in the mature forest. Forest type further significantly influenced the height, root length, and root collar thickness of seedlings and the proportion of exploration types of mycorrhizae.
\end{abstract}

Keywords: bark beetle; ECM fungi; exploration types; seedling morphology

\section{Introduction}

Ectomycorrhizal (ECM) symbiosis represents an important relationship between plants and basidiomycetous or ascomycetous fungi. Approximately 6000 tree species are involved in this relationship, including taxa from the plant families Pinaceae, Fagaceae, Betulaceae, and Corylaceae, which form large forests in temperate and boreal regions [1]. The ecological importance of mycorrhizal infection on seedling growth properties, productivity, and establishment has already been demonstrated $[2,3]$. Seedlings benefit also from connection to the mycorrhizal network representing mycelial linkage between plants of the same or even different plant species facilitating their growth, survival, establishment, or defensive chemistry [4]. This extensive mycelial network provides a competitive advantage to seedlings due to sufficient water and nutrient supply [4]. Within the mycorrhizal network, the plants seem to be supported irrespective of their size, status, or identity [5].

Natural disturbances are an integral part of the development cycle of forest ecosystems initializing forest succession leading to changes in tree composition and cover. In the temperate and boreal forests 
of Europe, the dominant disturbance events are caused by bark beetle outbreaks [6], windstorms [7], and fire [8]. Microclimatic conditions change after a disturbance that results in forest breakdown. This includes increased solar radiation and soil surface heating, greater input of precipitation and changes in soil moisture, and greater air circulation [9]. Forest ecosystem breakdown also impacts nutrient cycling and hydrology [10]. For instance, Štursová et al. [11] found that organic nitrogen was replaced by its mineral form, which negatively influenced the ECM fungal community [11,12]. Further, fungal community development is supposedly influenced by management of the affected forests, which affects soil compaction and related soil processes [13], soil microbiome, or the presence of small mammals $[13,14]$, etc. The resulting fungal species composition could influence the plant successional trajectory, which may, in turn, govern the fungal successional trajectory.

Above-ground herbivory by bark beetle affects ECM symbioses by reducing the carbon flow to the roots and fungal symbionts $[15,16]$. ECM colonization is usually not reduced, but the fungal composition is changed in favor of ECM morphotypes with low demands on photosynthates [17-20], which may affect the nutrient uptake and recovery of the host [21].

The Tatra Mountains (Slovakia) were affected by a serious windstorm in 2004, which destroyed about 12,600 ha of mountain spruce forest [22]. Following this historically largest calamity in the region, bark beetle started to spread in the surrounding spruce forest in 2007 and 2008 [23]. Some forest parts were almost completely destroyed with dead tree crown projection reaching $90 \%$, while other areas were not so seriously affected with around 6\% of dead tree crown projection [23]. Veselá et al. [20] reported a decrease in the proportion of ECM fungi in favor of saprotrophs in soils and pronounced changes in ECM community composition toward the most seriously infested forest type. The aim of this study was to determine whether a similar effect is occurring on seedling roots, which would indicate a direct effect of ECM community on forest regeneration. We hypothesized that ECM species diversity decreased toward the most seriously attacked forest type together with pronounced changes in species composition with predominating stress-tolerant species. We further expected more vigorous growth of spruce seedlings in not seriously attacked forests due to their connection to the mycorrhizal network supported by mature trees and constant microclimatic conditions under the protection of shelter wood.

\section{Materials and Methods}

\subsection{Study Area}

The research area in the Tatra Mountains, Slovakia (Figure 1), is characterized by a cold climate with mean annual temperature $4.0-5.3^{\circ} \mathrm{C}$ and mean annual precipitation $833-1000 \mathrm{~mm}$. The studied forest types are positioned in altitudes of 1120-1240 $\mathrm{m}$ a.s.l. in originally unmanaged spruce forest with larch admixture (Lariceto-Piceetum) on cambisols or podzosol with granodiorite or moraine bedrock $[23,24]$. Before the bark beetle attack, the forest was 130-140 years old, spruce accounted for 80 to $90 \%$, and canopy cover reached from 45 to $60 \%$ [20,23,24].

The K1 forest type is a forest attacked by bark beetle, with 10\% dead tree crown projection in 2015 . The bark beetle infestation started to spread in 2009. This forest part represents a slowly decaying forest composed of spruce with larch accompanied with fir and pine. Natural regeneration is represented mostly by spruce and rowan, with several individuals of larch, fir, and pine. The K2 forest type is a forest that has been destroyed by bark beetle since 2012, with standing and downed dead trees left in the forest. In this forest type, bark beetle infestation started to spread in 2007. Regeneration is poor, with mostly spruce and rowan. The REF forest type is a mature spruce forest not attacked by bark beetle. All three forest types were dominated by Vaccinium myrtillus L. 1753 in the understory, accompanied by Avenella flexuosa (L.) Drejer in K1 and REF, or Calamagrostis villosa (Chaix) J.F. Gmel. in K2 and REF (Table 1, Table S1). 


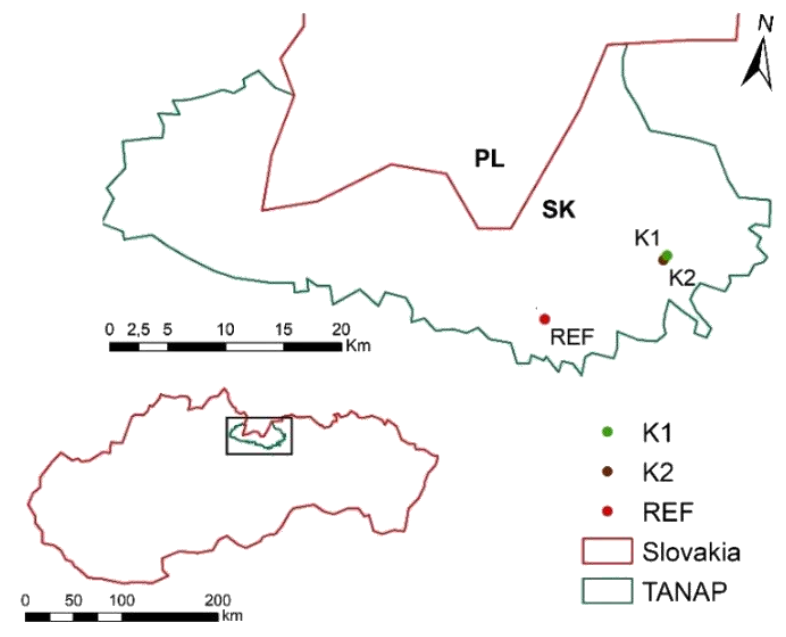

Figure 1. Map of the research area; Tatra Mountains National Park (TANAP), Slovakia (SK). Three types of forest; $\mathrm{K} 1$ = attacked by bark beetle, $\mathrm{K} 2$ = destroyed by bark beetle, REF = mature forest.

Table 1. Mean cover of trees, tree species composition, herb composition, tree regeneration, and coarse woody debris (CWD) in the K1 forest attacked by bark beetle, $\mathrm{K} 2$ forest destroyed by bark beetle, and REF mature forest.

\begin{tabular}{|c|c|c|c|}
\hline & K1 & K2 & REF \\
\hline tree cover & $43 \pm 10.9$ & 0 & $43 \pm 9.2$ \\
\hline cover of dominant trees & $\begin{array}{l}\text { Picea abies (L.) H. Karst. } \\
(26.5 \pm 4.9), \text { Larix decidua } \\
\text { Mill. }(15.0 \pm 7.1), \text { Abies alba } \\
\text { Mill. }(1.5 \pm 1.4), \text { Sorbus } \\
\text { aucuparia L. }(0.7 \pm 0.5)\end{array}$ & $\begin{array}{c}\text { Larix decidua }(1.0 \pm 0.6) \\
\text { Sorbus aucuparia }(3.8 \pm 1.3)\end{array}$ & $\begin{array}{l}\text { Picea abies }(36.0 \pm 9.8) \\
\text { Larix decidua }(7.0 \pm 2.9)\end{array}$ \\
\hline $\begin{array}{l}\text { cover of dominant } \\
\text { herbs ( } 3 \text { dominants) }\end{array}$ & $\begin{array}{l}\text { Vaccinium myrtillus }(37.7 \pm \\
5.2), \text { Avenella flexuosa }(10.2 \\
\pm 2.1), \text { Oxalis acetosella } \mathrm{L} . \\
(4.7 \pm 1.3)\end{array}$ & $\begin{array}{l}\text { Vaccinium myrtillus }(38.1 \pm \\
\text { 5.6), Calamagrostis villosa } \\
(10.4 \pm 4.5), \text { Epilobium } \\
\text { angustifolium L. }(8 \pm 2.1)\end{array}$ & $\begin{array}{c}\text { Vaccinium myrtillus (32.6 } \\
\pm 5), \text { Avenella flexuosa } \\
(14.3 \pm 3.3), \text { Calamagrostis } \\
\text { villosa }(11.4 \pm 2.5)\end{array}$ \\
\hline spruce seedling cover* & $0.5 \pm 0.3$ & $4.5 \pm 3$ & $2.6 \pm 1.3$ \\
\hline larch seedling cover * & $1 \pm 1$ & $0.2 \pm 0.1$ & $0.8 \pm 0.6$ \\
\hline rowan seedling cover* & $0.3 \pm 0.2$ & $2.4 \pm 0.8$ & $0.1 \pm 0.1$ \\
\hline CWD * & $2.5 \pm 0.7$ & $5.9 \pm 1.1$ & $0.5 \pm 0.3$ \\
\hline
\end{tabular}

\subsection{Seedlings and Ectomycorrhizae}

Twenty seedlings per forest type were collected in an area of $75 \times 75 \mathrm{~m}$ in September 2015 . The seedlings were at least $10 \mathrm{~m}$ apart from each other with the distance between microsites inferred from the observed variability of particular patches in mountain spruce forest.

The following morphometric parameters were measured: height of the aboveground part, root length, root collar perimeter, and age (according to the number of nodes). The surrounding vegetation cover of each selected seedling in a $5 \mathrm{~m}$ diameter circle was visually estimated together with coarse woody debris cover and litter cover.

In the laboratory, the root system of each seedling was carefully washed under tap water to remove soil particles and the upper, middle, and lower root fragments (with approximately 100 root tips per fragment) were documented under stereomicroscope (Canon EOS 1000D; Canon, Óta, Japan) to evaluate mycorrhizal root tips. Ectomycorrhizae were preliminarily divided into morphotypes and each morphotype was excised and stored in $70 \%$ ethanol for molecular identification. 


\subsection{DNA Extraction, $P C R$, and Sequencing}

Genomic DNA was extracted from ectomycorrhizal root tips using the DNeasy Plant Mini Kit (Qiagen, Hilden, Germany) according to the manufacturer's instructions. The extracted DNA was then used as a template for PCR amplification with primer pairs ITS1F/ITS4 [25,26] or ITS1F/ITS4B [27]. Multiple PCR products obtained from single root tip were separated from an agarose gel using the Gel Extraction Kit (Qiagen, Hilden, Germany). The PCR reaction was performed in a $25 \mu \mathrm{L}$ reaction mixture containing $1 \times$ reaction buffer (Bioline, London, $\mathrm{UK}$ ), $500 \mathrm{nM}$ of each primer, $0.75 \mathrm{U}$ of MyTaq DNA polymerase (Bioline, London, $\mathrm{UK}$ ), and $20 \mathrm{ng}$ of template DNA filled with $\mathrm{dH}_{2} \mathrm{O}$ up to $25 \mu \mathrm{L}$. The amplification conditions were $94{ }^{\circ} \mathrm{C}$ for $2.5 \mathrm{~min}$, followed by 37 cycles of $94{ }^{\circ} \mathrm{C}$ for $30 \mathrm{~s}, 55^{\circ} \mathrm{C}$ for $40 \mathrm{~s}, 72{ }^{\circ} \mathrm{C}$ for $30 \mathrm{~s}$, and a final extension of $72{ }^{\circ} \mathrm{C}$ for $4.5 \mathrm{~min}$. Sequencing of one strand using ITS4/ITS4B primer was performed by SEQme (Seqme, Dobřřšs, Czech Republic).

\subsection{Data Processing and Analysis}

The sequences were manually corrected (end trimming and replacing of ambiguous bases using IUPAC ambiguity code) in Chromas Lite v.2.6.5 (Technelysium Pty Ltd., Brisbane, Australia) and aligned against the UNITE [28] and GenBank [29] databases. A 97\% similarity threshold was the criterion for species approval. The sequences were deposited in GenBank (accession numbers: MN046989, MN047080). We made a species assignment for the whole photoset based on molecular identification of the morphotypes. Exploration types were adopted from Agerer et al. [30], online database www.deemy.de, or from our observations.

\subsection{Statistical Analysis}

Morphometric characteristics (height of aboveground part, length of main root, root collar perimeter, and age-derived from the number of nodes) and ECM species number (ECM species presence/absence data from a particular seedling) from twenty seedlings per forest type (K1, K2, REF) were tested by analysis of variance with Tukey's post-hoc contrasts in R 3.5.3 [31]. ECM species presence/absence data from a particular seedling were used to prepare a plot of ECM species occurrence from the twenty seedlings per forest type. Semi-quantitative data (ECM species from particular seedlings based on number of occupied studied root fragments) were analyzed by canonical correspondence analysis (CCA) and the proportion of exploration types based on ECM species presence/absence data assigned to a particular seedling were analyzed by redundancy analysis (RDA) in Canoco 5 [32]. CCA and RDA analyses were then conducted for each dataset using forward selection to determine the significant environmental variables (Monte Carlo permutation test, 999 permutations). The explanatory variables tested were: forest type, morphometric characteristics of the seedlings, and the cover of seedlings, litter, coarse woody debris, ferns, mosses, and herbs, including dwarf shrubs dominating in the vegetation surrounding the seedlings (Avenella flexuosa, Calamagrostis villosa, Calluna vulgaris (L.) Hull., Epilobium angustifolium, Homogyne alpina (L.) Cass., Juncus sp. L., Luzula luzuloides (Lam.) Dandy et Wilmott, L. sylvatica (Huds.) Gaudin, Maianthemum bifolium (L.) F.W. Schmidt, Oxalis acetosella, Rubus idaeus L., Sambucus sp. L., Vaccinium myrtillus, and V. vitis-idaea L.).

\section{Results}

\subsection{Morphometric Characteristics of Norway Spruce Seedlings}

Seedlings in the forest destroyed by bark beetle (K2) had statistically taller aboveground parts $(p<0.05)$, a longer main root $(p<0.05)$, and thicker root collar than seedlings from the forest attacked by bark beetle (K1) and the mature forest (REF) $(p<0.05$, Figure 2a-c, Table S2). On the other hand, seedlings from REF were older, had significantly more nodes (a proxy for age, six nodes on average) than seedlings from the K1 and K2 forest types (five nodes on average; $p<0.05$, Figure 2d). 

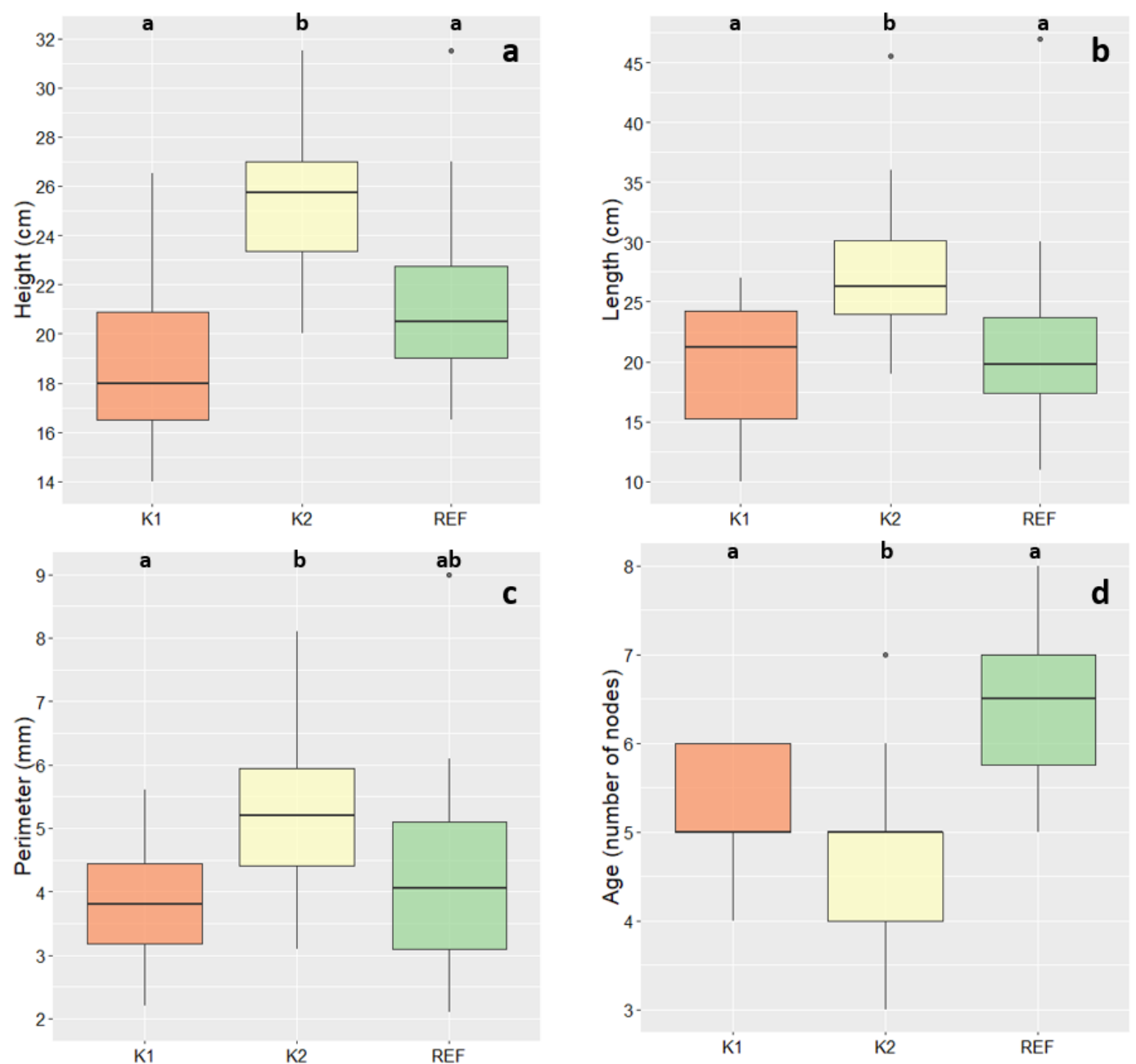

Figure 2. Morphometric characteristics of Norway spruce seedlings: (a) height of aboveground part, (b) main root length, (c) root collar perimeter, and (d) age in K1-seedlings in forest attacked by bark beetle; K2 - seedlings in forest destroyed by bark beetle; REF-seedlings in mature forest. The diagrams represent median, quartiles, and range $(1.5 \times \mathrm{IQR})$ from 20 seedlings.

\subsection{ECM Community on Root System of Norway Spruce Seedlings}

In total, we detected 30 ECM species; one taxon was identified only to the genus level and one to order (Table S1). The overall number of ECM taxa per forest type was the highest in the REF site (22 species) followed by K1 (19 species) and K2 (16 species). The average number of ECM species per seedling was the lowest in K2 with 2.7 species, followed by K1 and REF with 3.3, and 3.5, respectively (Figure 3). These differences were not statistically significant $(p=0.19)$.

The dominant ECM species in all three forest types was Tylospora fibrillosa (present in 16.9\% (K1), 30.2\% (K2), and 10.1\% (REF) of seedlings) and Cenococcum geophilum Fr., present in $15.4 \%$ (K1), $11.3 \%(\mathrm{~K} 2)$, and $23.2 \%$ (REF). These were accompanied by Amphinema byssoides (Pers.) J. Erikss., present in $10.8 \%$ (K1), 3.8\% (K2), and 10.1\% (REF), and Phialocephala fortinii (3.1\% (K1), 17.0\% (K2), and 1.5\% (REF), Figure 4). 


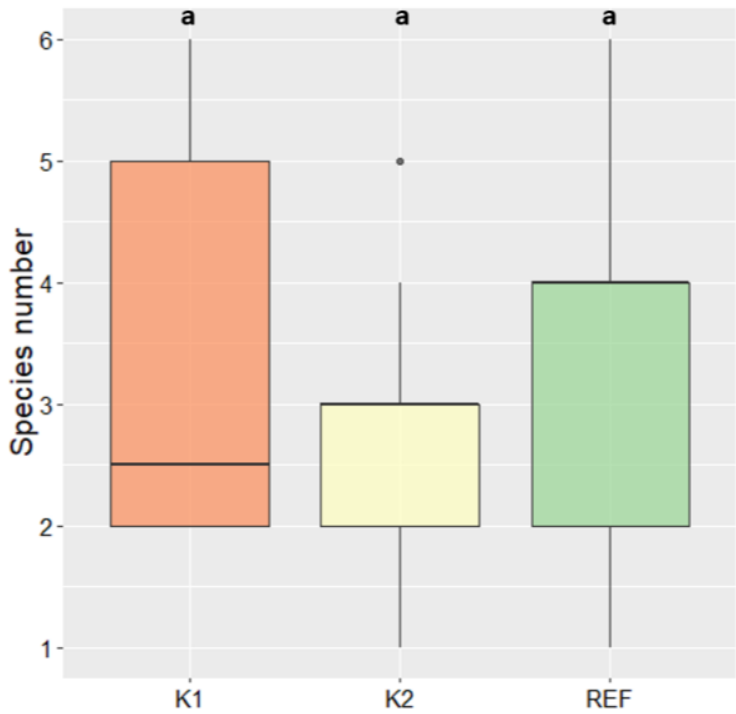

Figure 3. Ectomycorrhizal (ECM) species number from 20 Norway spruce seedlings per forest type in $\mathrm{K} 1$, the forest attacked by bark beetle; $\mathrm{K} 2$ forest destroyed by bark beetle; REF mature forest. The diagrams represent median, quartiles, and range $(1.5 \times \mathrm{IQR})$.

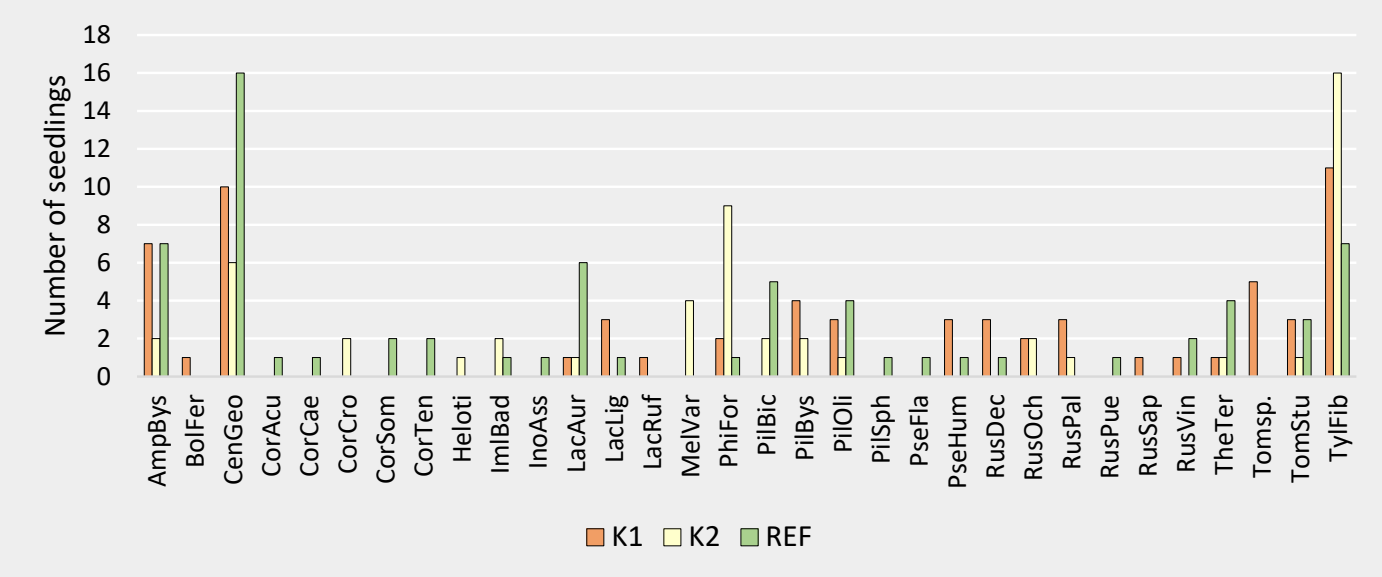

Figure 4. ECM species occurrence on Norway spruce seedlings. K1—forest attacked by bark beetle; K2-forest destroyed by bark beetle; REF-mature forest. AmpBys-Amphinema byssoides, BolFer-Boletus ferrugineus Schaeff., CenGeo-Cenococcum geophilum, CorAcu-Cortinarius acutus (Pers.) Fr., CorCae-Cortinarius caesiobrunneus Kytöv., Niskanen \& Liimat., CorCro-Cortinarius croceus (Schaeff.) Gray, CorSom-Cortinarius sommerfeltii Høil., CorTen-Cortinarius tenuifulvescens Kytöv., Niskanen \& Liimat., Heloti-Helotiales Nannf., ImlBad-Imleria badia (Fr.) Vizzini, InoAss—Inocybe assimilata (Britzelm.) Sacc., LacAur-Lactarius aurantiacus (Pers) Gray, LacLig_Lactarius lignyotus Fr., LacRuf-Lactarius rufus (Scop.) Fr., MelVar-Meliniomyces variabilis, PhiFor-Phialocephala fortinii, PilBic_Piloderma bicolor (Peck) Jülich, PilBys_Piloderma byssinum (P. Karst.) Jülich, PilOli_Piloderma olivaceum (Parmasto) Hjortstam, PilSph-Piloderma sphaerosporum Jülich, PseFla-Pseudotomentella flavovirens (Höhn. \& Litsch.) Svrček, PseHum-Pseudotomentella humicola M.J. Larsen, RusDec-Russula decolorans (Fr.) Fr. 1838, RusOchr-Russula ochroleuca (Pers.) Fr., RusPal—Russula paludosa Britzelm., RusPue-Russula puellaris Fr., RusSap-Russula sapinea Sarnari, RusVin-Russula vinosa Lindblad, TheTer-Thelephora terrestris Ehrh., Tomsp.-Tomentella sp., TomStup-Tomentella stuposa (Link) Stalpers, TylFib-Tylospora fibrillosa.

\subsection{Exploration Types}

Generally, short distance type (SD) was the most widespread exploration type (ET). These were represented, for example, by T. fibrillosa and C. geophilum, which were the dominant species in all forest 
types (35\% in $\mathrm{K} 1,68 \%$ in $\mathrm{K} 2$, and 38\% in REF). Medium distance fringe type (MDf), represented by the genus Cortinarius (Pers.) Grey and several species from the genus Piloderma Jülich (K1 29\%, K2 17\%, REF 33\%), and the contact type (C), represented by species from the genera Russula Pers. and Lactarius Pers. (K1 23\%, K2 8\%, REF 16\%), were less abundant. Medium distance smooth type (MDs) accounted for $11 \%$ in $\mathrm{K} 1,4 \%$ in $\mathrm{K} 2$, and $12 \%$ in REF, while long distance type (LD) was only $2 \%$ in $\mathrm{K} 1$ and REF and $4 \%$ in K2. The species assignment to ET is listed in Table S1.

\subsection{Environmental Drivers of Fungal Community Composition and Exploration Type Proportion}

Canonical correspondence analysis (CCA) was used to evaluate the effect of environmental variables on ECM species composition on seedlings (Figure 5, Table 2). Forest type explained $6.7 \%$ of the variability. The first axis separated seedlings in the K2 and REF forest types, while the K1 and REF forest types were separated on the second axis (Figure 5).

The effect of environmental variables on the proportions of exploration types on seedlings were assessed by redundancy analysis (RDA). The significant drivers were found to be forest type $(10.5 \%)$ and seedling microsite-cover of Luzula luzuloides and Epilobium angustifolium (14.7\%) (Table 2). Exploration type SD was associated with E. angustifolium cover, whereas $C$ type was related to L. luzuloides cover.

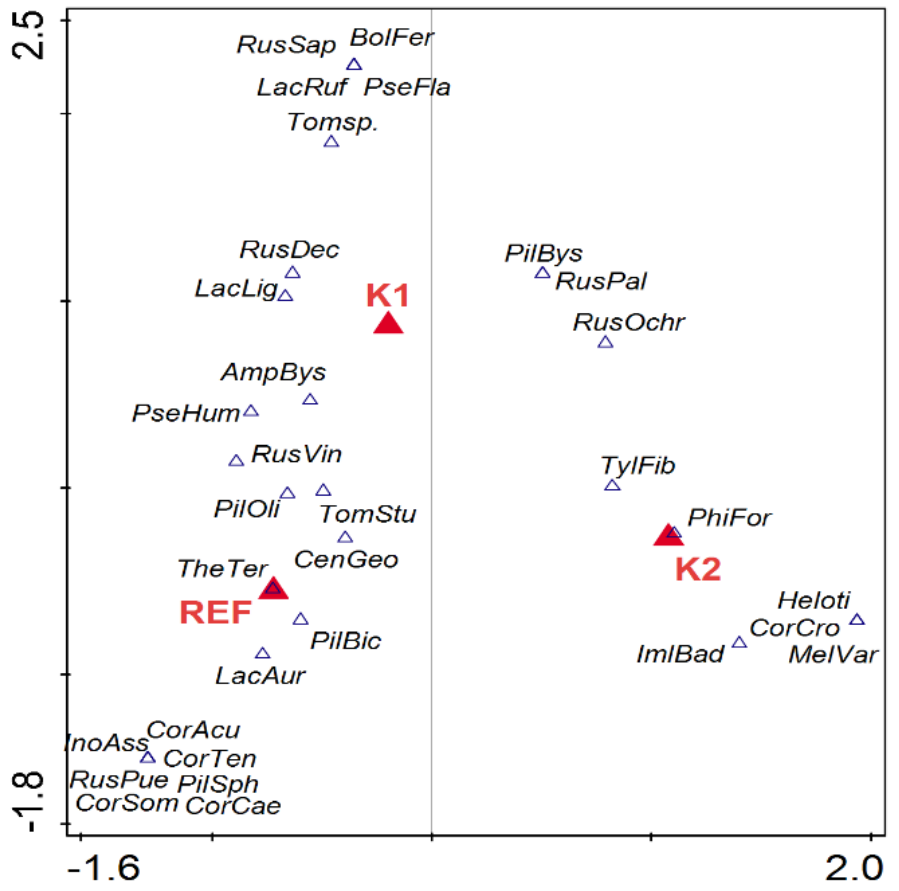

Figure 5. CCA analysis of ECM species composition of Norway spruce seedlings. Forest type was used as passive explanatory variable. K1, forest attacked by bark beetle; K2 forest destroyed by bark beetle; REF mature forest. AmpBys-Amphinema byssoides, BolFer-Boletus ferrugineus, CenGeo-Cenococcum geophilum, CorAcu-Cortinarius acutus, CorCae-Cortinarius caesiobrunneus, CorCro-Cortinarius croceus, CorSom-Cortinarius sommerfeltii, CorTen-Cortinarius tenuifulvescens, Heloti-Helotiales, ImlBad_Imleria badia, InoAss_Inocybe assimilata, LacAur_Lactarius aurantiacus, LacLig_Lactarius lignyotus, LacRuf-Lactarius rufus, MelVar-Meliniomyces variabilis, PhiFor-Phialocephala fortinii, PilBic-Piloderma bicolor, PilBys-Piloderma byssinum, PilOli-Piloderma olivaceum, PilSph-Piloderma sphaerosporum, PseFla-Pseudotomentella flavovirens, PseHum-Pseudotomentella humicola, RusDec-Russula decolorans, RusOchr-Russula ochroleuca, RusPal-Russula paludosa, RusPue-Russula puellaris, RusSap-Russula sapinea, RusVin-Russula vinosa, TheTer-Thelephora terrestris, Tomsp.—Tomentella sp., TomStup—Tomentella stuposa, TylFib_Tylospora fibrillosa. 
Table 2. Effect of environmental variables on ECM composition (canonical correspondence analysis (CCA)) and proportion of exploration types (redundancy analysis (RDA)) on Norway spruce seedlings in $\mathrm{K} 1$-forest attacked by bark beetle, K2—forest destroyed by bark beetle, and REF—mature forest.

\begin{tabular}{ccccc}
\hline Type of Analysis & Explanatory Variables & $\begin{array}{c}\text { Explained } \\
\text { Variability (\%) }\end{array}$ & Pseudo-F & $p$ \\
\hline CCA & $\begin{array}{c}\text { ECM composition } \\
\text { Site type (K1, K2, REF) } \\
\text { Exploration types } \\
\text { RD }\end{array}$ & 6.7 & 2.0 & 0.001 \\
& $\begin{array}{c}\text { Site type (K1, K2, REF) } \\
\text { Vegetation cover: Epilobium angustifolium, } \\
\text { Luzula luzuloides }\end{array}$ & 10.5 & 3.3 & 0.011 \\
\hline
\end{tabular}

\section{Discussion}

Our data on ECM species composition of seedlings in forest types differently affected by bark beetle did not support the hypothesis on species diversity decrease toward the most seriously attacked forest type. Even if total number of ECM species on seedling roots per forest type decreased (REF-K1-K2), it was not significant in the case of the number of ECM species per seedling. Similarly, Vašutová et al. [14] did not find a significant difference in species number colonizing seedling roots in a windstorm destroyed area and mature forest; the only significant decrease was reported from a burnt forest stand. On the contrary, Peter et al. [33] found decreased species number with increased forest pollution intensity. Disturbances impact the ECM community in different ways depending on their intensity, duration, degree of microhabitat conditions disruption and present ECM species pool.

On the other hand, the ECM species community composition on Norway spruce seedlings changed, which was consistent with our hypothesis. When comparing this alteration with one detected in a soil fungal community after bark beetle infestation [20], where Elaphomyces Nees sp. and Russula spp. dominated in mature forests, while Piloderma spp., Wilcoxina Chin S. Yang et Korf sp., and Thelephora terrestris in bark beetle destroyed forest, the change in the ECM community on seedling roots was not so dramatic. Similarly, Vašutová et al. [14] detected less pronounced changes in the ECM community on seedlings than in soil. The ECM fungal community in soils is usually more complex in comparison with seedlings because of the presence of spores and mycelium of species associated with all tree age classes, while seedlings host only a specific ECM fungal spectrum related to that particular age [34,35].

Tylospora fibrillosa and Cenococcum geophilum were dominant on seedling roots in all three forest types, but their abundance differed between forest types. T. fibrillosa occupied twice as many seedlings in K2 than in REF, while C. geophilum showed an opposite trend. REF was characterized by the presence of Lactarius, Russula, and Cortinarius species, associated with healthy forests [20,36,37], with some were still found in K1. A similar trend was detected by Peter et al. [33], who found T. fibrillosa increased its abundance on seedlings in a locality affected by air pollution with increasing damage intensity, while Russula and Lactarius species preferred sites with lower damage levels. One of the possible explanations for the increase in T. fibrillosa in seriously damaged forests is its ability to degrade remnants of decaying wood to acquire extra carbon due to their possessing lignin peroxidase genes [38]. Another explanation can be the prevalence of ECM fungal species with low demands on photosynthates following defoliation [17-19]. Probably Phialocephala fortinii and Meliniomyces variabilis, which increased their abundance in $\mathrm{K} 2$ compared to $\mathrm{K} 1$ and REF, are such species. P. fortinii is commonly treated as an endophyte but it was also found to create ectomycorrhizae with Scots pine [39], similarly as root-associated M. variabilis, which was found to simultaneously colonize Scots pine and Vaccinium [40,41]. The ericaceous shrubs may then serve as a source of fungal inoculum enabling the colonization of spruce seedlings in $\mathrm{K} 2$ where the mature forest was destroyed and true ECM fungi decreased their diversity and abundance [20]. ECM species from the ordo Helotiales were already described to increase its abundance in beetle-killed stands [21]. 
ECM fungal species with saprotrophic capacities may further indirectly support seedling nutrition through access of mineralized nutrients [3]; this is consistent with the biggest seedlings found in $\mathrm{K} 2$. However, no direct relationships between morphological parameters and ECM species composition on seedlings were observed. Thus, the more intensive growth of seedlings in $\mathrm{K} 2$ was probably associated with increase light level connected to greater $\mathrm{CO}_{2}$ assimilation and photosynthetic rate [42] and decreased competition from mature trees for water and nutrients [43].

These above mentioned findings are closely related to the changes in the proportion of exploration types. The short distance exploration type almost exclusively prevailed on seedlings in the K2 forest type (68\%); this type was less abundant in other forest types (ca 35\%). The SD exploration type, including taxa as T. fibrillosa or C. geophilum, are thought to have lower plant $C$ demands for their mycelial growth [44] in contrast to the more $C$ demanding medium distance fringe type [45] or contact type, which prefer wet soils with high organic matter content [46,47]. These latter types increased in K1 with ongoing bark beetle infestation. Changes in exploration types following environmental changes are also thought to affect $\mathrm{C}$ and $\mathrm{N}$ cycling [48]. The proportion of exploration types on seedlings was partly explained by the forest type itself but a larger part of the variability was explained by cover of the herbs Epilobium angustifolium and Luzula luzuloides (Table 2). ECM fungi are impacted by chemical compounds leached into soil from litter or decaying plants or from root exudates $[49,50]$. Cote and Thibault [51] demonstrated that some ECM fungi are inhibited (Paxillus involutus (Batsch.) Fr., Laccaria proxima (Boud.) Pat., L. bicolor (Maire) P.D. Orton, T. terrestris), while others are stimulated (Hebeloma cylindrosporum Romagn. and C. geophilum) when exposed to leaf leachate of raspberry [52]. Similarly, stimulatory or inhibitory effects could be seen in the relationship between the above-mentioned herbs and ECM fungi on roots of Norway spruce seedlings.

\section{Conclusions}

Bark beetle infestation influenced the ECM fungal community on Norway spruce seedlings. We detected increased abundance of stress tolerant Tylospora fibrillosa, Meliniomyces variabilis, and Phialocephala fortinii and considerable decrease in species associated with healthy forests. Seedlings in forests affected by bark beetle possessed a higher percentage of short distance exploration mycorrhizal type. The bark beetle outbreak also influenced seedling morphological parameters. Seedlings were significantly bigger in the destroyed forest, which is probably associated with forest stand opening and may also be supported by the above-mentioned stress tolerant ECM species.

Supplementary Materials: The following are available online at http://www.mdpi.com/1999-4907/10/9/740/s1, Table S1: List of sequences of ECM fungi found on roots of spruce seedlings, Table S2: Seedling morphological parameters and surrounding vegetation cover.

Author Contributions: Conceptualization, P.C. and M.V.; methodology, P.C. and M.V.; investigation, P.V. and K.H.; formal analysis, P.V., K.H., and M.E.-J.; data interpretation, P.V., M.V., and K.H.; data curation, P.V. and K.H.; writing-original draft preparation, P.V. and M.V.; writing—review and editing, P.C.; funding acquisition, P.C.

Funding: This research was funded by the Ministry of Education, Youth, and Sports of CR within the National Sustainability Program I, grant number LO1415.

Acknowledgments: This work was supported by the Ministry of Education, Youth, and Sports of CR within the National Sustainability Program I (NPU I), grant number LO1415. We thank Lenka Effenberková, Filip Holub, Zdeňka Kovaříková, Ondřej Cudlín, and Jan Purkyt for field and lab assistance.

Conflicts of Interest: The authors declare no conflict of interest.

\section{References}

1. Martin, F.; Kohler, A.; Murat, C.; Veneault-Fourrey, C.; Hibbett, D.S. Unearthing the roots of ectomycorrhizal symbioses. Nat. Rev. Microbiol. 2016, 14, 760-773. [CrossRef] [PubMed]

2. Dickie, I.A.; Oleksyn, J.; Reich, P.B.; Karolewski, P.; Zytkowiak, R.; Jagodzinski, A.M.; Turzanska, E. Soil modification by different tree species influences the extent of seedling ectomycorrhizal infection. Mycorrhiza 2006, 16, 73-79. [CrossRef] [PubMed] 
3. Jonsson, L.M.; Nilsson, M.; Wardle, D.A.; Zackrisson, O. Context dependent effects of ectomycorrhizal species richness on tree seedling productivity. OIKOS 2001, 93, 353-364. [CrossRef]

4. Gorzelak, M.A.; Asay, A.K.; Pickles, B.J.; Simard, S.W. Inter-plant communication through mycorrhizal networks mediates complexadaptive behaviour in plant communities. AoB Plants 2015, 7, 50. [CrossRef] [PubMed]

5. Van der Heiden, M.G.A.; Horton, T.R. Socialism in soil? The importance of mycorrhizal fungal networks for facilitation in natural ecosystems. J. Ecol. 2009, 97, 1139-1150. [CrossRef]

6. Seidl, R.; Müller, J.; Hothorn, T.; Bässler, C.; Heurich, M.; Kautz, M. Small beetle, large-scale drivers: How regional and landscape factors affect outbreaks of the European spruce bark beetle. J. Appl. Ecol. 2016, 53, 530-540. [CrossRef]

7. Papaik, M.J.; Canham, C.D. Species resistance and community response to wind disturbance regimes in northern temperate forests. J. Ecol. 2006, 94, 1011-1026. [CrossRef]

8. Fischer, A.; Marshall, P.; Camp, A. Disturbances in deciduous forest ecosystems of the northern hemisphere: Their effects on both recent and future forest development. Biodivers. Conserv. 2013, 22, 1863-1893. [CrossRef]

9. Gömöryová, E.; Střelcová, K.; Škvarenina, J.; Bebej, J.; Gömöry, D. The impact of windthrow and fire disturbances on selected soil properties in the Tatra national park. Soil Water Res. 2008, 3, S74-S80. [CrossRef]

10. Treu, R.; Karst, J.; Randall, M.; Pec, G.J.; Cigan, P.W.; Simard, S.W.; Cooke, J.E.; Erbilgin, N.; Cahill, J.F., Jr. Decline of ectomycorrhizal fungi following a mountain pine beetle epidemic. Ecology 2014, 95, 1096-1103. [CrossRef]

11. Štursová, M.; Šnajdr, J.; Cajthaml, T.; Bárta, J.; Šantrůčková, H.; Baldrian, P. When the forest dies: The response of forest soil fungi to a bark beetle-induced tree dieback. ISME J. 2014, 8, 1920. [CrossRef] [PubMed]

12. Avolio, M.L.; Tuininga, A.R.; Lewis, J.D.; Marchese, M. Ectomycorrhizal responses to organic and inorganic nitrogen sources when associating with two host species. Mycol. Res. 2009, 113, 897-907. [CrossRef] [PubMed]

13. Hartmann, M.; Niklaus, P.A.; Zimmermann, S.; Schmutz, S.; Kremer, J.; Abarenkov, K.; Lüscher, P.; Widmer, F.; Frey, B. Resistance and resilience of the forest soil microbiome to logging-associated compaction. ISME J. 2014, 8, 226-244. [CrossRef] [PubMed]

14. Vašutová, M.; Edwars-Jonášová, M.; Veselá, P.; Effenberková, L.; Fleischer, P.; Cudlín, P. Management regime is the most important factor influencing ectomycorrhizal species community in Norway spruce forests after windthrow. Mycorrhiza 2018, 28, 221-233. [CrossRef] [PubMed]

15. Gehring, C.; Bennett, A. Mycorrhizal-fungal-plant-insect interactions: The importance of a community approach. Environ. Entomol. 2009, 38, 93-102. [CrossRef] [PubMed]

16. Hubbard, R.; Rhoades, C.C.; Elder, K.; Negron, J. Changes in transpiration and foliage growth in lodgepole pine trees following mountain pine beetle attack and mechanical girdling. For. Ecol. Manag. 2013, 289, 312-317. [CrossRef]

17. Saikkonen, K.; Ahonen-Jonnarth, U.; Markkola, A.M.; Helander, M.; Tuomi, J.; Roitto, M.; Ranta, H. Defoliation and mycorrhizal symbiosis: A functional balance between carbon sources and below-ground sinks. Ecol. Lett. 1999, 2, 19-26. [CrossRef]

18. Kuikka, K.; Härmä, E.; Markkola, A.; Rautio, P.; Roitto, M.; Saikkonen, K.; Ahonen-Jonnarth, U.; Finlay, R.; Tuomi, J. Severe defoliation of scots pine reduces reproductive investment by ectomycorrhizal symbionts. Ecology 2003, 84, 2051-2061. [CrossRef]

19. Saravesi, K.; Markkola, A.; Rautio, P.; Roitto, M.; Tuomi, J. Defoliation causes parallel temporal responses in a host tree and its fungal symbionts. Oecologia 2008, 156, 117-123. [CrossRef]

20. Veselá, P.; Vašutová, M.; Edwards-Jonášová, M.; Cudlín, P. Soil fungal community in Norway spruce forests under bark beetle attack. Forests 2019, 10, 109. [CrossRef]

21. Karst, J.; Erbilgin, N.; Pec, G.J.; Cigan, P.W.; Najar, A.; Simard, S.W.; Cahill Jr, J.F. Ectomycorrhizal fungi mediate indirect effect of a bark beetle outbreak on secondary chemistry and establishment of pine seedlings. New Phytol. 2015, 208, 904-914. [CrossRef] [PubMed]

22. Fleischer, P.; Homolová, Z. Tatra Mts. as the object for long-term ecological research of natural disturbances. Životné Prostredie 2016, 50, 40-43.

23. Šebeň, V.; Konopka, B.; Bošela, M.; Pajtík, J. Contrasting development of declining and living larch-spruce stands after a disturbance event: A case study from the High Tatra Mts. For. J. 2015, 61, 157-166. [CrossRef] 
24. Fleischer, P. Windfall research and monitoring in the High Tatra Mts, objectives, principles, methods and current status. Contrib. Geophys. Geod. 2008, 38, 233-248.

25. Gardes, M.; Bruns, T.D. ITS primers with enhanced specificity for basidiomycetes: Application to the identification of mycorrhizae and rusts. Mol. Ecol. 1993, 2, 113-118. [CrossRef] [PubMed]

26. White, T.J.; Bruns, T.; Lee, S.; Taylor, J. Amplification and Direct Sequencing of Fungal Ribosomal RNA Genes for Phylogenetics. In PCR Protocols: A Guide to Methods and Applications; Innis, N., Gelfand, D., Sninsky, J., White, T., Eds.; Academic Press Inc.: New York, NY, USA, 1990.

27. Nikolcheva, L.G.; Bärlocher, F. Taxon-specific fungal primers reveal unexpectedly high diversity during leaf decomposition in a stream. Mycol. Prog. 2004, 3, 41-49. [CrossRef]

28. Abarenkov, K.; Henrik Nilsson, R.; Larsson, K.H.; Alexander, I.J.; Eberhardt, U.; Erland, S.; Høiland, K.; Kjøller, R.; Larsson, E.; Pennanen, T.; et al. The UNITE database for molecular identification of fungi-recent updates and future perspectives. New Phytol. 2010, 186, 281-285. [CrossRef] [PubMed]

29. Benson, D.A.; Cavanaugh, M.; Clark, K.; Karsch-Mizrachi, I.; Lipman, D.J.; Ostell, J.; Sayers, E.W. GenBank. Nucleic Acids Res. 2007, 41, 36-41. [CrossRef] [PubMed]

30. Agerer, R. Fungal relationships and structural identity of their ectomycorrhizae. Mycol. Prog. 2006, 5, 67-107. [CrossRef]

31. R Development Core Team. R: A Language and Environment for Statistical Computing; The R Foundation for Statistical Computing: Vienna, Austria, 2019. Available online: http://www.R-project.org/ (accessed on 3 March 2019).

32. Ter Braak, C.J.F.; Šmilauer, P. Canoco Reference Manual and User's Guide: Software for Ordination, version 5.0; Microcomputer Power: Ithaca, NY, USA, 2012.

33. Peter, M.; Ayer, F.; Cudlín, P.; Egli, S. Belowground ectomycorrhizal communities in three Norway spruce stands with different degrees of decline in the Czech Republic. Mycorrhiza 2008, 18, 157-169. [CrossRef]

34. Visser, S. Ectomycorrhizal fungal succession in jack pine stands following wildfire. New Phytol 1995, 129, 389-401. [CrossRef]

35. Wu, Y.T.; Wubet, T.; Trogisch, S.; Both, S.; Scholten, T.; Bruelheide, H.; Buscot, F. Forest age and plant species composition determine the soil fungal community composition in a Chinese subtropical forest. PLoS ONE 2013, 8, e66829. [CrossRef] [PubMed]

36. Beule, L.; Grüning, M.M.; Karlovsky, P.; L-M-Arnold, A. Changes of Scots pine phyllosphere and soil fungal communities during outbreaks of defoliating insects. Forests 2017, 8, 316. [CrossRef]

37. Pec, G.J.; Karst, J.; Taylor, D.L.; Cigan, P.W.; Erbilgin, N.; Cooke, J.E.; Simard, S.W.; Cahill, J.F. Change in soil fungal community structure driven by a decline in ectomycorrhizal fungi following a mountain pine beetle (Dendroctonus ponderosae) outbreak. New Phytol. 2017, 213, 864c873. [CrossRef] [PubMed]

38. Tedersoo, L.; Köljalg, U.; Hallenberg, N.; Larsson, K. Fine scale distribution of ectomycorrhizal fungi and roots across substrate layers including coarse woody debris in a mixed forest. New Phytol. 2003, 159, 153-165. [CrossRef]

39. Otgonsuren, B.; Lee, M. Pinus sylvestris can form ectomycorrhiza with Phialocephala fortinii. Taiwan J. For. Sci. 2012, 27, 265-281.

40. Grelet, G.; Johnson, D.; Vralstad, T.; Alexander, I.J.; Anderson, I.C. New insights into the mycorrhizal Rhizoscyphus ericae aggregate: Spatial structure and co-colonization of ectomycorrhizal and ericoid roots. New Phytol. 2010, 188, 210-222. [CrossRef]

41. Sietiö, O.; Tuomivirta, T.; Santalahti, M.; Kiheri, H.; Timonen, S.; Sun, H.; Fritze, H.; Heinonsalo, J. Ericoid plant species and Pinus sylvestris shape fungal communities in their roots and surrounding soil. New Phytol. 2018, 218, 738-751. [CrossRef]

42. Robakowski, P.; Wyka, T.; Samardakiewicz, S.; Kierzkowski, D. Growth, photosynthesis, and needle structure of silver fir (Abies alba Mill.) seedlings under different canopies. For. Ecol. Manag. 2004, 201, 211-227. [CrossRef]

43. Teste, F.; Simard, S. Mycorrhizal networks and distance from mature trees alter patterns of competition and facilitation in dry Douglas-fir forests. Oecologia 2008, 158, 193-2013. [CrossRef]

44. Haas, J.C.; Street, N.R.; Sjödin, A.; Lee, N.M.; Högberg, M.N.; Näsholm, T.; Hurry, V. Microbial community response to growing season and plant nutrient optimisation in a boreal Norway spruce forest. Soil Biol. Biochem. 2018, 125, 197-209. [CrossRef] 
45. Pena, R. Nitrogen acquisition in ectomycorrhizal symbiosis. In Molecular Mycorrhizal Symbiosis; Martin, F., Ed.; John Wiley \& Sons: New York, NY, USA, 2016; pp. 179-196.

46. Bakker, M.R.; Augusto, L.; Achat, D.L. Fine root distribution of trees and understory in mature stands of maritime pine (Pinus pinaster) on dry and humid sites. Plant. Soil 2006, 286, 37-51. [CrossRef]

47. Guignabert, A.; Delerue, F.; Gonzalez, M.; Augusto, L.; Bakker, M.R. Effects of management practices and topography on ectomycorrhizal fungi of maritime pine during seedling recruitment. Forests 2018, 9, 245. [CrossRef]

48. Rosinger, C.; Sandén, H.; Matthews, B.; Mayer, M.; Godbold, D.L. Patterns in ectomycorrhizal diversity, community composition, and exploration types in European Beech, Pine, and Spruce forests. Forests 2018, 9, 445. [CrossRef]

49. Bending, G.D.; Read, D.J. Lignin and soluble phenolic degradation by ectomycorrhizal and ericoid mycorrhizal fungi. Mycol. Res. 1997, 101, 1348-1354. [CrossRef]

50. Gallet, C.; Pellissier, F. Phenolic compounds in natural solutions of a coniferous forest. J. Chem. Ecol. 1997, 23, 2401-2412. [CrossRef]

51. Cote, J.F.; Thibault, J.R. Allelopathic potential of raspberry foliar leachates on growth of ectomycorrhizal fungi associated with black spruce. Am. J. Bot. 1988, 75, 966-970. [CrossRef]

52. Javaid, A. Allelopathic interactions in mycorrhizal associations. Allelopathy J. 2007, 20, $29-42$.

(C) 2019 by the authors. Licensee MDPI, Basel, Switzerland. This article is an open access article distributed under the terms and conditions of the Creative Commons Attribution (CC BY) license (http://creativecommons.org/licenses/by/4.0/). 